\title{
Natureza e Cultura na Civilização do Inhame: a origem dos clones e dos clãs ${ }^{1}$
}

\author{
André-Georges Haudricourt ${ }^{1}$ \\ Tradução: Yves M. Seraphim² \\ Revisão de Tradução: Jérémy Deturche ${ }^{2}$
}

${ }^{1}$ Botânico, antropólogo e linguista francês

${ }^{2}$ Universidade Federal de Santa Catarina, Florianópolis, Santa Catarina, Brasil 


\section{Resumo}

Neste texto, André-Georges Haudricourt (1911-1996), etnólogo, etnobotânico, agrônomo e linguista francês, avança sua argumentação a favor da homologia entre atitudes humanas perante outros humanos e perante animais e plantas, apresentada em um artigo anterior traduzido ao português em 2013 (HAUDRICOURT, 1962). Por meio do estudo etnográfico dos Kanak da Nova Caledônia, demonstra-se como a dinâmica entre roças e capoeiras, caracterizada por sua reversibilidade e geração de novas variedades agrícolas, é homóloga aos modos como os neocaledônios percebem a vida e a morte, a instauração de um chefe, a dinâmica clânica, além de sua relação com estrangeiros.

Palavras-chave: Natureza/Cultura. Kanak. Sistemas Agrícolas.

\section{Abstract}

In this text, André-Georges Haudricourt (1911-1996), French ethnologist, ethnobotanist, agronomist and linguist goes on with his argument in favour of a homology between human attitudes towards other humans and towards animals and plants, discussed in a previous article translated into portuguese in 2013 (HAUDRICOURT, 1962). Through the ethnographic study of the Kanak of New Caledonia, it is demonstrated how the dynamics between gardens and fallows, characterized by its reversibility and generation of new agricultural varieties, is homologous to the how the new caledonians perceive life and death, chief establishment, clan dynamics and also their relation with foreigners.

Keywords: Nature/Culture. Kanak. Agricultural Systems. 


\title{
1 Introdução
}

Para Jacques Barrau em memória de sua ajuda durante minha estada na Nova Caledônia.

\begin{abstract}
Oceania é uma dessas regiões privilegiadas em que a história parece Ater preparado experiências sociológicas, das quais hoje podemos observar o resultado: encontra-se de fato populações de mesma origem praticando ou não a criação animal, umas vivendo sobretudo da pesca, outras, sobretudo, da agricultura.
\end{abstract}

A Nova Caledônia, na qual durante dois ou três milênios não havia animais domésticos e onde, na falta de mamíferos, a caça tinha um espaço mínimo, pode ser tomada como exemplo do que chamarei de a civilização do inhame.

Não ignoro o papel que a pesca marítima teve ou ainda tem. É ela que permitiu o povoamento inicial (provindo provavelmente das Novas Hébridas); é ela que explica a organização político-social, como se pode perceber na comparação entre a Nova Caledônia propriamente dita (Grande Terre) e as Ilhas Lealdade, Fiji e a Polinésia, onde se encontra a civilização da pesca no mar quente, a mais típica.

Mas antes de entrar no cerne da questão, precisamos dar algumas indicações de botânica e de agronomia, as quais, por ora, não se espera que estejam na bagagem do etnólogo. 


\section{Sobre Tubérculos e Grãos ${ }^{2}$}

Dos vegetais, o homem consome as reservas - sobretudo amiláceas - que permitem que as plantas aguentam a temporada menos propícia. Durante a estação demasiada seca ou demasiada fria, as partes aéreas da planta ressecam e morrem, essa planta sobrevive apenas em um tubérculo enterrado ou em sementes. Nos climas "contrastados", em que a umidade volta bruscamente com o calor, maior a quantidade de reserva, mais vigoroso será o jovem broto, mais ele obterá luz à custa de seus vizinhos e mais chances ele terá de sobreviver. Assim, nas regiões de clima típico de monções, nos desertos de chuvas torrenciais, porém raras, nas terras periodicamente inundadas, a seleção natural tinha como que preparado para o homem plantas alimentares que ele utilizou quando inventou a cozinha.

O tubérculo pertence ao que se chama de uma planta perene. A cada ano a planta originada de um tubérculo forma ao seu lado ou um pouco mais longe um ou vários outros tubérculos, sendo, no entanto, biologicamente sempre o mesmo indivíduo.

A semente, ao contrário, provém de uma flor e produz um novo indivíduo. Ela resulta de uma reprodução sexuada análoga àquela dos animais ou do homem: o indivíduo recebe a metade de seu patrimônio hereditário de um elemento masculino e a outra metade de um elemento feminino (as metades não sendo idênticas, os descendentes de um mesmo casal também não o são, ao contrário dos verdadeiros gêmeos de um mesmo patrimônio hereditário). Sem dúvida, na maior parte das plantas os sexos não são separados, mas o fato de que o elemento masculino - o pólen - é um fino pó suscetível de ser transportado pelo vento ou pelos insetos é suficiente para assegurar às plantas todas as vantagens da reprodução sexuada: principalmente uma grande variabilidade. Tal variabilidade permitiu sua sobrevivência ao longo dos tempos geológicos, ao passo que o clima e a repartição das terras e dos mares se modificavam. Inversamente, essa vantagem da reprodução sexuada, por sua vez, por meio do viés da seleção natural manteve a sexualidade nas plantas.

O tubérculo, então, garante bem a perenidade do indivíduo, um pouco menos sua dispersão, ainda que em algumas plantas isso seja 
assegurado relativamente bem por tubérculos aéreos ou bulbos que podem se destacar, rolar sobre o solo ou flutuar sobre a água. De fato, nas plantas de tubérculos, a dispersão à longa distância e a variedade, necessárias à sobrevivência da espécie são asseguradas pelas sementes: pequenos grãos alados transportados pelo vento (Dioscoreaceae), pequenas bagas comidas pelos pássaros (Araceae), etc.

Em contrapartida, as sementes, relativamente volumosos, de plantas anuais estão submissas a duas tendências opostas: quanto menores, melhor garantirão a dispersão, porém acumularão reservas menores; quanto maiores, acumularão reservas superior, porém sua dispersão será mais difícil. É por isso que as regiões de origem dos nossos cereais são (para o milho, o painço e a cevada) as estepes onde há disseminação por ventos fortes ou por bandos de herbívoros, ou ainda (para o arroz) às margens de corpos d'água onde o transporte se faz pela própria água.

\section{O Clone e a Linhagem}

Se compararmos agora a agricultura de plantas com grãos (por exemplo aquela do Oriente Médio, do Egito e da Mesopotâmia que está na origem da agricultura europeia) à agricultura de tubérculos, de partida constatamos diferenças externas no trabalho agrícola. “O gesto augusto do semeador" de cereais jogando um punhado de sementes sobre o solo, e o gesto do ceifeiro que empunha um tufo inteiro para cortá-lo, se opõe evidentemente aos gestos do cultivador de inhame que introduz com cuidado o pedaço de inhame em uma cova preparada de antemão e que, no momento da colheita, arrancá-lo rasgando a terra ao redor. A cultura da batata, única planta dos agricultores de tubérculos que pôde ser introduzida na Europa (graças ao clima análogo às terras altas andinas e às regiões temperadas), pode, comparado à cultura do trigo, dar-nos uma ideia dessa oposição.

No entanto, uma outra diferença, mais profunda e menos visível, tem a ver com o modo de reprodução das plantas cultivadas. A cultura de plantas a grãos é uma cultura de linhagens: a cada estação obtêmse indivíduos diferentes; o clima e o solo podem favorecer certos indivíduos em vez de outros, podem acontecer hibridizações com os 
parentes selvagens da planta cultivada. Se o agricultor não escolher suas sementes entre as mudas mais bonitas, suas plantas degeneram. Quando, em vez de escolher as mudas se contenta em separar os grãos mais pesados, ele acaba podendo selecionar também as ervas daninhas que acompanham o cereal e, como diz Plínio, nas regiões frias da Europa o trigo e a cevada se degeneram em centeio e aveia.

A cultura de tubérculos é uma cultura de clone: a cada estação da cultura os mesmos indivíduos são replantados para serem colhidos na estação seguinte. A palavra clone designa o conjunto de tubérculos provenientes, por transplantes sucessivos, do mesmo indivíduo. Tratase, portanto, de uma agricultura cuja base biológica é absolutamente estável e o agricultor sabe que em caso de uma má colheita, os únicos responsáveis são o solo, seu trabalho e a chuva, e que ele não pode incriminar alguma "degeneração". (O que para nós é chamado de degeneração da batata é uma doença viral propagada por picadas de insetos, e nada tem a ver com uma variação hereditária).

Ademais, para evitar colocar todos seus ovos na mesma cesta, o cultivador de tubérculos deve dispor de toda uma gama de clones, um mais resistente à seca, outro à umidade etc., a fim de se prevenir contra as incertezas meteorológicas. Enquanto que o cultivador de grãos cultiva linhagens que distingue pouco e que, como resultado de sua reprodução sexuada, frente às anomalias meteorológicas, demonstram a mesma plasticidade que a vegetação espontânea ${ }^{3}$.

\section{Os Clones na Nova Caledônia}

Na agricultura tradicional da Nova Caledônia, encontramos ao lado dos tubérculos amiláceos de diferentes espécies pertencentes à família das Dioscoreaceae: Dioscorea alata L. (inhame verdadeiro), Dioscorea esculenta Burk., Dioscorea bulbifera L., Dioscorea pentaphylla L., Dioscorea nummularia Lam., e das Araceae: Colocasia antiquorum Sch. (taro), Amorphophallus campanulatus Brume, Alocasia macrorhiza L., plantas de outras famílias igualmente cultivadas via muda: Taetsia sp. (cordilyne), Musa sapientum (bananeira), Musa troglodytarum L. (fehi), Artocarpus altilis Fos. (fruta-pão), Hibiscus tiliaceus L. (bourao), Hibiscus manihot L., Saccharum offìinarum L. (cana-de-açúcar), Syzygium malaccensis. 
Em contrapartida, para o coqueiro (Cocos nucifera L.) e para o Cycas que não se deixam multiplicar via muda, a semente germinada encontrada sob a árvore é replantada. As únicas plantas que apresentam o problema de ter que semear grãos são a cabaça e o feijão. A cabaça (Lagenaria vulgaris Sér.) praticamente desapareceu frente à cabaça americana (Crescentia cujete L.) e às garrafas. É provável que a dispersão das sementes ocorresse no momento em que se esvaziava a fruta antes de ser utilizada. O feijão local (Dolichos Lablab L.) ainda é cultivado, mas também se encontra de maneira subespontânea, e é possível perguntarse se esse cultivo é antigo, porque outras plantas subespontâneas são protegidas e consumidas sem terem sido objeto de cultivo, como a erva-moura (Solanum nigrum L.) e a serralha (Sonchus oleraceus L.).

Se examinarmos agora o número de clones conhecido para cada espécie, constatamos uma grande desigualdade: muitas das espécies citadas acima são relíquias das quais conhecemos somente um ou dois clones, em compensação três espécies - o inhame verdadeiro, o taro e a cana-de-açúcar - apresentam uma gama extraordinária. Há um século, Vieillard havia anotado no norte da Grande Terre uma vintena de nomes de clones de taro e uma quarentena para a cana-de-açúcar. Alguns anos mais tarde, de Greslan descrevia uma trintena de clones de inhame da região de Touho. Recentemente, J. Barrau encontrou em Wunjo 25 nomes de clones de inhames, 31 em Bobope, 25 nomes de clones de taro em Ateu ${ }^{4}$. Durante minha primeira missão em 1959, encontrei 67 nomes de clones de inhame, 26 nomes de clones de taro e 27 de cana de açúcar em Yambé, 51 nomes de inhame, 15 de taro e 28 de cana-de-açúcar em Koumac. Em 1963 encontrei em Tiaué 40 nomes de inhame, 20 de taro e 23 de cana-de-açúcar e, enfim, em PaamaBaye, mais de 72 nomes de inhame e 39 de cana-de-açúcar (mas os homens se recusaram de me falar dos taros, assunto das mulheres). Para a bananeira, raramente se ultrapassa dez nomes de clones.

Alguns desses clones foram introduzidos há menos de um século. Esses são os que figuram o nome de uma missão católica - Saint-Louis, Wagap, Saint-Philippe - ou o nome de outra ilha - Papua, Santo, Belep, Futuna, etc. - nomes que se encontra para a dezena de clones de batata-doce, de introdução igualmente recente. Mas a maioria 
dos nomes não se presta a tal interpretação e, depois de um século, a decadência da civilização autóctone, consecutiva à colonização que reduziu as superfícies cultiváveis e da diminuição da população por causas das epidemias, deve ter reduzido o número de clones.

Será que se deve imaginar que um ou dois séculos antes de nossa era, uma pequena frota de pirogas duplas trouxe os primeiros imigrantes com uma centena de clones de inhame, tanto quanto de taro, tanto quanto de cana-de-açúcar? Deve-se ao contrário supor que durante um milênio existiram relações marítimas regulares e, por conseguinte, trocas regulares de clones entre as ilhas melanésias e o continente asiático?

Isso não está excluído, mas uma outra solução pode ser considerada.

\section{A Roça e a Capoeira}

A agricultura neocaledônia era uma agricultura itinerante, embora implicasse o preparo do solo, em montículos para os inhames e em terraços irrigáveis para os taros. Quando ao fim de alguns anos a terra se esgotava, montículos e terraços eram montados em outros lugares e o solo descansava de dez a vinte anos. Roças podiam em seguida serem reinstaladas no mesmo local graças a aterramentos efetuados outrora, uma vez os arbustos derrubados e as árvores descascados e queimados. Atualmente, pode-se ver em todo lugar, nas pastagens da colonização, o relevo dos montículos e dos terraços de taro.

A colheita jamais era perfeita e um broto de inhame ou de taro podia permanecer na capoeira, florir e dar sementes que depois germinavam e produziam novos indivíduos. É na capoeira, no mato que assim se formavam novos clones.

Ao longo de uma enquete fonológica em 1959, deparei-me com uma monossílaba que significava "ir procurar algo nas capoeiras". De início, pensei que se tratava, em caso de um episódio de fome, de ir ver se não restava alguma planta comestível nas antigas roças. No entanto, era surpreendente que tal significação se exprimia em uma palavra breve, portanto utilizada frequentemente. Na verdade, explicaram-me, se tratava sobretudo de ir procurar algum broto ou muda para transplantar. 
As bananeiras de frutas de comestíveis são híbridos interespecíficos estéreis. Quando, muito raramente, produzem sementes, elas engendram somente bananeiras de sementes não comestíveis. Apesar da presença de clones de bananeiras de rizomas comestíveis, os quais poderiam dar sementes, é provável que a dezena de antigos clones na Nova Caledônia não tenha se formado localmente e seu estudo citogenético, bem como a comparação com os clones de outras ilhas, seria reveladora de antigas migrações e relações marítimas.

Uma outra planta reveladora do passado é uma leguminosa com tubérculo, nomeado no francês local de "magnania" (Pueraria thunbergiana Benth $=$ P. lobata). Ela não é cultivada; é uma planta de coleta, cujos tubérculos são coletados anualmente no mês de agosto; não é um alimento utilizado para casos de fome, mas uma comida muito apreciada, uma comida de chefia. Coisa curiosa, a planta floresce, mas nunca dá sementes, nem ali nem nas outras ilhas melanésias. É necessário ir às Filipinas ou ao Japão para encontrá-las. Existe então na Nova Caledônia somente dois ou três clones dessa espécie que portam nomes distintos em todas as línguas do país. É certo que a planta não veio sozinha e que as aves não puderam transportar sementes desde o Japão, tampouco tubérculos (que pesam muitos quilos) desde ilhas vizinhas.

Eu facilmente imaginaria melanésios chegando na Nova Caledônia com três ou quatro clones de cada espécie. As espécies férteis deram nascença a novos clones, os quais os agricultores descobriram e multiplicaram; é o caso do inhame, do taro e da cana-de-açúcar. As espécies estéreis viram seus clones indefinidamente cultivados (caso da bananeira), mas no caso da magnania, a planta persistia indefinidamente nas capoeiras de modo que, ao fim de um milênio de cultivo itinerante, os dois ou três clones dessa espécie estavam difundidas em todo lugar, e já não era mais necessário cultivá-las, embora se continuasse a colhê-las ${ }^{6}$.

\section{O Natural e o Sobrenatural}

Eu gostaria de demonstrar as ligações entre agricultura melanésias e as concepções "religiosas" da Nova Caledônia. Citarei as principais 
passagens em que Maurice Leenhardt fala de "deuses" em sua obra Les Gens de la Grande Terre (Paris, N.R.F., 1937), em particular páginas 176-177, 46 e 178:

O topo da linha que figura sobre o esquema da linhagem paterna, os respectivos antepassados permanecem os iniciadores do poder dos descendentes, e lhes asseguram sua propiciação. Eles são os deuses, os Bao.

Escuta-se a todo instante os Kanak pronunciarem tal vocábulo Bao, enquanto que o termo rhe, que significa totem, é bastante raro nas conversas. A palavra deus está carregada de sentidos tão diversos em nossa língua francesa que é necessário especificar o termo Bao, para não colocar em nossa interpretação dados que o nativo ignora.

Toda marca anormal da pele, mancha de lepra, impetigo, etc., é a marca que uma lança invisível lhe atingiu, lançada por um Bao, um deus.

Todo susto na escuridão, fogo fátuo, silêncio ou barulho, toda manifestação insólita é obra de um deus. [...]

Todos os locais desnudados são os lugares onde os passos das danças dos deuses impediram o crescimento da grama. [...]

Os deuses falam com os homens. Nos sonhos eles instruem, revelam, fazem presságios [...] O Bao é também criador [...]

Quando curiosos impertinentes querem que os Kanak lhes expliquem a origem dos petróglifos, numerosos na ilha, eles respondem: "Os Bao os fizeram". Todas manifestações concretas cuja origem é desconhecida são dadas como obras dos deuses.

Esses deuses têm nomes. E em breve tais nomes são esquecidos. Em poucas gerações vê-se os deuses nascerem e morrerem. Indiferentes ou solícitos aos vivos, são defuntos antigos ou novos. Podem tomar a figura humana e desempenhar o papel de fantasmas que se misturam à sociedade dos vivos [...]

O encontro com um fantasma é algo frequente [...]

Isso ajuda a entender a atitude para nós tão desconcertante do Kanak hesitante a tomar como ser vivo o indivíduo que há na sua frente em carne e osso. Um dos meus alunos havia sido marinheiro em um cargueiro. Em Port-Vila, nas 
Novas Hébridas, ele viu no cais um indígena que fixava sobre si os olhos brilhantes: confuso, ele o observa, pois ele se parecia com um de seus primos desaparecido da aldeia há anos e tido por morto. E como o outro, feliz, não tirou os olhos de cima dele, porque reconheceu seu parente, nosso marinheiro se curva sobre a amurada e em sua língua sussurra:

"Tu és um morto ou tu és vivo?" Isso significa: Diga-me rápido, tu és meu antigo camarada, ou tu és um fantasma? [...]

Essas atitudes dos Kanak atuais esclarecem as dos Kanak da história: Cook conta que perante seus marinheiros eles não se incomodaram. Os Kanak os deixaram circular enquanto que eles mesmos permaneceram em seus lugares, ocupados em suas próprias atividades, somente espiando os movimentos dos europeus. No dia seguinte, concordaram em guiá-los pelos caminhos da montanha, e assim o fizeram, ao que parece, calmamente. Houve, assim, um reencontro no mesmo local, mas sem confrontos, sem incidentes, sem real troca e Cook ficou muito impressionado. A causa dessa distância aparece hoje sem dificuldade: quando barcos de velas brancas vieram do horizonte, os caledônios viram descer humanos espertos e de rosto claro, e não hesitaram em ver neles os fantasmas dos mortos de suas famílias, aqueles para os quais rezaram em seus altares rústicos, os ancestrais, os deuses encarnados. E eles permaneceram quietos enquanto tais deuses passeavam pela aldeia e os ajudaram somente quando requisitaram ajuda. As pessoas do além eram, naquele dia único, visíveis: em vez de experimentar misteriosamente sua existência, observava eles se movimentarem sob uma forma concreta $[\ldots]$

Ainda recentemente, as pessoas da costa oeste chamavam as roupas europeias de peles dos deuses. O nome de Bao é dado aos velhos dotados de sabedoria ou de loucura. Eu mesmo, há tempos missionário no país, ouvi advertirem uma criança que tocava meus sapatos: "Não o toque, é um Bao".

Os vivos que levam uma vida diferente da comum e, por consequência, extraordinária já são deuses, equiparados a $[\ldots]$

Essas sobreposições da vida e da morte na representação dos deuses não são efeito de uma incoerência. O limite 
da vida e da morte é aquele que distingue dois estados do ser, e não o ponto onde se opõe o ser e o nada [...] Como o homem é o ser no estado vivo, o Bao é o ser no estado defunto. Ele não o é de maneira geral ou genérica. Ele é o cadáver mesmo. Nos funerais o mestre de cerimônias, para fazer transportar o morto, diz "Tragam o Bao".

Poderíamos resumir as indicações do missionário dizendo que os bao são os seres do outro mundo: deuses, mortos, fantasmas; o que corresponde a distinção europeia do natural e do sobrenatural. Mas temos o direito de transpor à Melanésia nossas noções de deuses, de sobrenatural?

\section{A Cultura e a Natureza}

Não seria melhor considerar o homem vivo como relacionado a sua roça, domínio da vida cotidiano, do previsto, do espetado, do racional, uma vez que os clones das plantas cultivadas são, lá, sempre idênticos a si mesmos?

Em contrapartida, o mato onde se deposita os mortos não seria a capoeira, roça passada, ou roça futura, domínio do imprevisto, do acidental, do anormal, benéfico quando se encontra um novo clone de melhor gosto do que aqueles que se conhece, maléfico quando o novo clone, por um retorno atávico, contém cristais irritantes ou substâncias tóxicas da planta selvagem?

O homem não é "cultivado" senão durante sua vida; em sua morte ele retorna à natureza. Mas essa natureza não é em nenhum grau "natural" no sentido francês da palavra, de modo que prefiro opor "cultura" à "incultura". Assim, as observações de Maurice Leenhardt se explicam melhor. Por exemplo, a mesma palavra (e o mesmo conceito) é usada para "cadáver" e para "deus"; é que o homem vivo que come inhames é o "cultivado", ao passo que o morto se torna "inculto", como a roça abandonada se torna uma capoiera. Mas, do mesmo modo que a capoiera pode se tornar novamente uma roça, o "inculto" pode se tornar novamente "cultivado", e aparece, então, como o "deus", ancestral dos clãs. 
Nas narrativas tradicionais, as "ressurreições", retornos à vida, operam-se pela ingestão de um alimento "cultivado", seja a batatakanak (Syzygium rnalaccensis) que cai na boca do cadáver flutuante, seja inhame grelhado, que é o "inculto" a princípio vomita e normalmente apenas consegue ingerir após três tentativas.

Nas narrativas de volta à vida coletadas no centro (Houailou), o inhame é acompanhado da cana-de-açúcar, e sua absorção é precedida da cuspida de planta (processo usual dos curandeiros). Nas narrativas do Norte (Koumac), a absorção do inhame é precedida por uma fricção de nozes bancoulas. Um texto de Maurice Leenhardt me parece particularmente significativo, o qual é intitulado "o aleijado", que resumo:

Um homem foi assassinado quando voltava de um ritual pilou; apenas seu espírito voltou para casa para se despedir de sua mulher e de seu filho, em seguida, foi à floresta desapareceu em uma árvore. Seu filho queria trazê-lo de volta à vida. Ele subiu em Kondu, desenterrou um inhame, cortou uma cana-de-açúcar e foi ao lugar onde outrora seu pai desapareceu. Ele fez um sacrifício e orou: "Pai, avô, que chova muito, que o trovão estoure, que desça uma inundação"

O trovão então estourou, atingiu a árvore onde seu pai estava encerrado. O tronco se abriu, o jovem saltou, agarrou seu pai, deu-lhe um pedaço de inhame; porém o pai o vomitou; o jovem o deu um outro, o qual o pai engoliu, depois lhe ofereceu uma cana-de-açúcar, o qual o pai vomitou; na segunda tentativa, o pai a engoliu? ${ }^{7}$.

Aproximaremos agora esse texto e um documento inédito (que também resumo) de J. Guiart sobre a origem de um clã atualmente extinto, os Pwaatao, chefes de Poo:

Um dia que as pessoas de Poo haviam ido fazer terraços para taros nas montanhas e brincavam arremessando suas lanças enquanto voltavam à aldeia, um desconhecido se infiltrou entre eles para brincar e depois desapareceu nas bordas da floresta. O mesmo se deu no segundo dia, mas desta vez dois homens do clã Nèènu o notaram; no terceiro dia, eles o seguem e o veem desaparecer em uma árvore (Calophyllum montanum). No dia seguinte, eles se põem de 
tocaia e, quando ele chega, agarram-no. O homem resiste e lhes diz: "O que vocês estão fazendo com o homem de Gorodu-Pwaatao, coração de "houp" (Montrouziera) e de "tamanou" (Calophyllum)" os outros dois respondem: "Nós te agarramos para te levar até a aldeia" - "Não, eu fico em Gorodou-Pwaatao,é aqui minha morada" - "Não, não é certo ficar aqui no mato, é melhor viver na aldeia". Eles o carregam até a aldeia. Lá, eles grelham um inhame, o homem o come e o vomita; dão-no novamente, ele o engole e o vomita mais uma vez; enfim, na terceira vez, ele o engole e o retém. Está acabado, e então os dois homens o dizem: "Tu serás nosso chefe".

Remontando a genealogia dos clãs, chega-se, ao cabo de sete ou oito gerações àquilo que Leenhardt chamava de "deuses", àquilo que os outros missionários chamaram de "diabos" (é essa última expressão que as pessoas utilizam em francês) e que eu chamarei sobretudo de "incultos. Assim como a origem de um clone vem de uma planta "inculta" achada no mato, a origem de um clã vem de um "inculto" arrancado a força do mato.

Em Goro, ao sul da Grande Terre, contaram-me a história de uma garota que havia desejado ir ver o célebre Kétéwaré em Lifou:

Ela chega em sua morada; dir-se-ia que ele parece como uma serpente ou um lagarto; ele mora em uma "madeira-petróleo" (Fagraea schlechterii) em Nyégoté, de onde sai apenas à noite para ir dormir com as mulheres... Finalmente, uma mulher velha fendeu a casca da árvore, ele volta lá na aurora, quer re-entrar, mas sai no outro lado. "Como isso é possível?" Ele diz, e, assim, permanece humano. A mulher o faz um medicamente e termina de o curar. Finalmente, ele assume "a religião de Samoa".

Em outras palavras, para a narradora, trata-se de um dos chefes de Lifou que se converteu ao protestantismo na primeira metade do século XIX.

Melhor, um dos meus informantes, Marcel Pwèla Inon, diz-me que há trinta anos, as pessoas de Maré haviam descoberto a cerca de vinte quilômetros de Nouméa uma família de "diabos" na mata. Os pais fugiram, mas as pessoas haviam conseguido capturar um garotinho, o qual havia adotado e nomeado Paul. Marcel Pwèla chamou para 
confirmar um Pîibèè, ao qual recorda que haviam trabalhados juntos durante a guerra, para o exército americano, com o tal Paul, que era um homem de força acima da média.

O inculto, que é a origem do clã, pode ser um estrangeiro.

\section{O Estrangeiro e o Inculto}

Então, por que dizer que os melanésios tomaram Cook e os primeiros navegadores por "deuses"? Eles o tomaram por aquilo que era realmente, "incultos", gente que não se alimentavam de inhame e que não pertenciam a sua civilização.

O interesse dos melanésios pelo estrangeiro "a cultivar" se manifesta hoje de um modo espantoso: suas aldeias são realmente invadidas por plantas ornamentais americanas, asiáticas ou mesmo africanas. Toda vez que conseguirem encontrar uma muda de uma planta nova, eles a levam consigo; eles trocam aquelas que possuem. Uma aproximação se impõe com as trocas de crianças tão comuns na Oceania; o "evoluído" 8 , que recusa a dar suas crianças para serem "transplantadas" nas famílias vizinhas, é taxado de egoísta e associal. Que contraste com a endogamia, com a xenofobia do cultivador de cereais, que deve a cada ano "separar o trigo do joio" e que não encontrará jamais nada de bom para cultivar no exterior de suas roças!

Espero ter demonstrado nessas poucas páginas que o conhecimento de princípios de botânica e de agronomia é mais útil ao etnólogo do que o conhecimento de grupos sanguíneos ou de impressões digitais.

\section{Notas}

1 Esta obra foi publicada originalmente como: Haudricourt, André-Georges. Nature et culture dans la civilisation de l'igname: l'origine des clones et des clans. L'Homme, 1964, v. 4, n. 1. p. 93-104

2 [N.T.] Exceto por uma ocorrência, os termos que escrevemos como "semente" e "grão" são traduções da mesma palavra graine. Quando o sentido botânico (como parte da morfologia vegetal) e reprodutivo estão em destaque optamos por "semente", ao passo que "grão" é empregado quando se enfatiza o uso por parte dos humanos.

3 O contraste indicado acima opõe os inventores de agriculturas de cereais anuais e agricultura de tubérculos. O milho e o arroz são cereais adotados tardiamente pelos cultivadores de tubérculos: o grão de milho é plantado, depois se faz um monte a seu redor; o arroz é transplantado e são selecionadas as variedades autofecundadas 
que dão linhagens puras quase tão estáveis quanto os clones. É assim que os montanheses da Indochina têm uma gama de linhagens de arroz, comparável à gama de clones de inhame da Nova Caledônia.

4 Jacques Barrau, L'agriculture vivrière autochtone de la Nouvelle-Calédonie, Nouméa, 1956, Bibliogr., p. 49 e 62.

5 [N.T.] Traduzimos respectivamente o termo champ por "roça" e jachère por "capoeira", palavra comum em grande parte do interior brasileiro para se referir a matos que crescem no lugar do que havia sido uma roça, além de apresentar qualidades específicas, diferenciando-se de outros tipos de mato. Ademais, ainda quanto ao segundo vocábulo, pode haver certa sinonímia com o vocábulo "pousio", porém o termo possui uma história técnica particular que decorre de contextos não tropicais, além parecer implicar uma maior continuidade nas ações que os humanos efetuam no lugar, visando em primeiro lugar a recuperação da terra para novos plantios.

6 O clima neocaledônio não é um clima “contrastado"; a vegetação cresce continuamente: as madeiras das árvores não apresentam os anéis anuais que demonstram a retomada do crescimento. As plantas alimentares, tanto as cultivadas, quanto as de coleta, são originários do continente asiático ou de grandes ilhas (Nova Guiné) e muito poucas puderam ser transportadas por pássaros ou pelas correntes marinhas antes da chegada do homem (a exemplo da tacca, da taetsia e, talvez, do coqueiro). No entanto, Maurice Leenhardt supunha, baseando-se no mito de origem dos povos do centro, que uma era de coleta havia precedido a de agricultura, e acreditava na chegada tardia do coqueiro (o que, conforme toda evidência, é, senão mais velho, pelo menos tão antigo quanto a chegada do homem). Sem dúvida o coqueiro não desempenha um grande papel nos mitos ou no ritual, mas a Sra. Jacqueline Kesarhérou me fez notar justamente que o cagu, pássaro corredor próprio da Nova Caledônia e que os colonos tomaram como emblema, é também totalmente ignorado em mitos e ritos. Por este motivo, poder-se-ia dizer que sua introdução é recente!

7 Maurice Leenhardt, Documents néo-calédoniens, Paris (t. I, Ethn. IX), 1932, p. 389- 396, e para as "voltas à vida": ibidem, p. 180, 253, 413 e 420, 469. Para o norte, cf. Jean Guiart, Contes et Légendes de la Grande Terre, Nouméa, 1957, p. 20,73 e 75 .

8 [N. T.] O evoluído [l'évolué] era para a administração colonial francesa um termo para designar os indivíduos "europeizados" ou "assimilados" que abandonavam as práticas nativas, ou mesmo as repudiavam.

\section{Referências}

BARRAU, Jacques. L'agriculture vivrière autochtone de la NouvelleCalédonie. Nouméa, 1956.

GUIART, Jean. Contes et Légendes de la Grande Terre. Nouméa, 1957.

HAUDRICOURT, André-Georges. Domesticação de animais, cultivo de plantas e tratamento do outro. Série Tradução. Brasília: Departamento de Antropologia, UnB, 2013 [1962].

LEENHARDT, Maurice. Documents néo-calédoniens, Paris, (t. I, Ethn. IX), 1932. 


\section{Apêndice}

Clones de Dioscorea alata (inhame verdadeiro) conhecidos em Yambé (1959), língua Jawé

$\begin{array}{ccc}\text { juxuic } & \text { ku } & \text { tâla } \\ \text { kora-kajanu } & \text { koyi } & \text { kupuny } \\ \text { puacek } & \text { kubwiit } & \text { cixaaen } \\ \text { pangara } & \text { kumhwek } & \text { tâla pebwan } \\ \text { hyagic } & \text { koviye } & \text { kapedan } \\ \text { uyelo } & \text { kuwa } & \text { cedala } \\ \text { kilira } & \text { kubwaaô } & \text { chaat } \\ \text { beea } & \text { chaamat } & \text { kora } \\ \text { wavenyada } & \text { nikola } & \text { puuang } \\ \text { kajanu } & \text { wanabiyo } & \text { kugeena } \\ \text { deen } & \text { kumajop } & \text { kacagulop } \\ \text { pwaban } & \text { move } & \text { bwaaheleo } \\ \text { pwaauran } & \text { kumanyô } & \text { kuwaba } \\ \text { kupiyap } & \text { thuxemani } & \text { kamôve } \\ \text { nexilan } & \text { kudim } & \text { wavulura } \\ \text { waanhyaat } & \text { kaokaok } & \text { hôda } \\ \text { mwadac } & \text { cankôk } & \text { kukac } \\ \text { janap } & \text { kelerua } & \text { unytana } \\ \text { kupû } & \text { kuhwek } & \text { kuchaanô } \\ \text { malongany } & \text { maxelo } & \text { kupe } \\ \text { chawaoo } & \text { kanôot } & \text { kuhyen } \\ \text { kucha } & \text { kabooe } & \\ \text { kudila } & \text { bigenchep } & \end{array}$

Clones de taro conhecidos em Yambé (1959), língua Jawé Clones de terra irrigada com tubérculos comestíveis

$\begin{array}{ccc}\text { jali } & \text { doming } & \text { habu } \\ \text { waxap } & \text { jali miia } & \text { domwa } \\ \text { hyalam } & \text { povo } & \\ \text { thala } & \text { jali axap } & \end{array}$


Clones de terra irrigada com folhas comestíveis thaaoda

chamooa

bwixooc

\section{Clones de terra seca}

$\begin{array}{ccc}\text { kaje } & \text { unegat } & \text { phurunâ } \\ \text { kaje puny } & \text { ujanu } & \text { mateeo } \\ \text { hyankenpaek } & \text { pwandoli } & \text { barevin } \\ \text { divu } & \text { chanaboe } & \text { wanmai } \\ \text { janbwala } & \text { yomeeo }(=\text { than maaop }) & \text { kaheec }\end{array}$

\section{Clones de cana-de-açúcar em Tnekngenpaik (1959),} língua Pijé

$\begin{array}{ccc}\text { wala } & \text { deuwa } & \text { kaneok } \\ \text { wala pûthâ } & \text { dekali } & \text { sabu } \\ \text { wipiin } & \text { sigudiian } & \text { thilipi } \\ \text { bwadap } & \text { dimwâ } & \text { huwan } \\ \text { mita } & \text { gorea } & \text { huwan hulo } \\ \text { hoaai digan } & \text { jan hay a } & \text { huwan magat } \\ \text { pulaoa } & \text { jan keet } & \text { didu } \\ \text { gala } & \text { sibwi } & \text { thaaket } \\ \text { gala peepo } & \text { hinkula } & \text { thaawa } \\ \text { khûndaahma } & \text { sat } & \text { kayova }\end{array}$




\section{Clones de inhame verdadeiro (D. alata) na língua Paicî D’Arapô (1963), Paama-Baye}

ajunâgôn
taikâ
taikâ êmwî
bato
cikêi
waapwi wéta
puë
ciéédara
êdëu
mwàda âiiï
mwâda jô
gôrôpô
gôrôpô âboro
iidi gôrôpô
gôrôpô màrâdo
gôrôpô kèrèpïrrii
gôrôpô aukôô
gôrôpô pu j agô
gôrôpô mârù
gôrôpô wanèmîjô
tëuri
tuauru
waradé
tomiï
bwatanâ

\author{
pwakuta \\ bêêkè \\ kakkînîtôa \\ bwau \\ kôkôci \\ bwilênà \\ citiimwâ \\ biili
}

nàgôri wânâ aumâkëtéâ

tanà urudô

pwârâ wâi

nâgôri numwà

awi

awi ilëri

bwûcûrû

dee nyèrè

dee géré

dee kacôa

dee imîî

dee gôrôwâ

dee îrîcô

dee wâdû

dee gomî

dee gôônyèrè

dee êtërëpuu

\author{
kumàjô \\ pôia \\ pabua \\ êôki
}

êôki durubwërë

wëtôpwe wànàpuwa

$$
\text { âboro }
$$

mwâda pêtê

dee kôkôci

dee dorowâji

dee cânàmîrî

ère atë

ère pwëpié

nùméa

guënù

buké

dipu nâràkôô

popwaalé

wërë itau

mëruga

waakuruta jiirimârù

kaapwû 


\section{Clones de cana-de-açúcar, id.}

$\begin{array}{ccc}\text { waji niïmwa } & \text { ûrû } & \text { nyïâdi } \\ \text { bwara } & \text { éaarô } & \text { gôriwiigéca } \\ \text { bwanâànîupo } & \text { tërëkâdii } & \text { jêmôtô } \\ \text { mîta } & \text { tûunââ } & \text { déuwë } \\ \text { pumù } & \text { câgôdû } & \text { uakàrâjitëmù } \\ \text { dêê } & \text { bwibwi } & \text { jêi } \\ \text { camwàdu } & \text { purawa } & \text { tëpwe } \\ \text { cëurunagôrôbwau } & \text { ciibwi } & \text { wiihpwûrûé } \\ \text { wâré } & \text { miduwâjé } & \text { kacaa } \\ \text { doromârâânyè } & \text { jétéa } & \text { uuwëpwâlo } \\ \text { pwê } & \text { wâniâ } & \text { wâjijawé } \\ \text { warémwàri } & \text { pitëpaacîrînâîé } & \\ \text { gôtârâtikakara } & \text { cipô } & \end{array}$

Recebido em 19/11/2019

Aceito em 19/12/2019

\section{André-Georges Haudricourt (1911-1996)}

Foi diretor honorário de pesquisas no CNRS, FR. Discípulo de Marcel Mauss, dedicou-se especialmente à linguística e à etnobotânica e, no que tange à antropologia, atuou como um dos precursores da tecnologia cultural, vertente francesa da antropologia da técnica e tecnologia.

\section{Yves M. Seraphim (Tradutor)}

Graduando em Antropologia pela Universidade Federal de Santa Catarina. Endereço para correspondência: Campus da Universidade Federal de Santa Catarina, CFH - Centro de Filosofia e Ciências Humanas. Trindade, Florianópolis, SC. CEP: 88040-900.

E-mail: yves.seraphim@gmail.com

\section{Jérémy Deturche (Revisor da Tradução)}

Doutor em Antropologia pela Université Paris Ouest - Nanterre, Professor do Departamento de Antropologia da UFSC.

Endereço para correspondência: Campus da Universidade Federal de Santa Catarina, CFH - Centro de Filosofia e Ciências Humanas, Trindade, Florianópolis, SC. CEP: 88040-900.

E-mail: jeremy.deturche@gmail.com 